or three times a week, or in fine weather sea bathing if subsequent chill can be guarded against. If the Vichy douche-massage bath is available at a neighbouring clinic or spa, this is probably the ideal method of treatment for such cases at almost any stage, combining as it does in one treatment the three desiderata of physio-therapy, heat, movement and massage.

Advice as to the prevention of the recurrence of lumbago should include common sense principles such as moderation in all things, including recreations of the nature of gardening, which involve lumbar strain, and work if this is conducive to the localisation of such attacks; the avoidance of any mild trauma, such as starting a car by hand, which may be known to aggravate the condition must also be insisted upon; and, finally, the necessity for early medical assistance in the event of a relapse before the condition has had time to re-establish itself must be emphasized.

\title{
STENOSIS OF THE ESOPHAGUS.
}

By Ronald W. Raven, F.R.C.S. (Eng.)

This subject is of great practical importance to the doctor and patient. The former is often confronted with almost unsurmountable difficulties when deciding upon the treatment to be adopted and the latter has generally to face a grave prognosis. At the present time the surgery of the œsophagus is being developed and increasing numbers of operations are being performed for pathological conditions which hitherto were regarded as hopeless. Further progress will be made in the future based upon experimental work which is now proceeding.' The time appears opportune for a review of some common varieties of œsophageal stenosis with the management thereof.

\section{A.-Congenital Stenosis.}

Congenital œsophageal stenosis is more common than is generally supposed. Doubtless many patients die without the correct diagnosis having been made. These patients are infants one or two weeks old who are brought because they are unable to retain their food and are considered to vomit everything. The majority of such infants die, but there is a minority which can be saved providing the correct diagnosis is made and adequate treatment instituted.

Numerous varieties of congenital deformity of the œsophagus have been described; I will confine my remarks to the following types:-

\section{I.-Complete Esophageal Stenosis with Esophago-Tracheal Fistula.}

The marked constancy of the morphology of this condition has been recognised by many observers. The oesophagus commences in the usual way but ends blindly forming a thin sac whose lower end is about the level of the bifurcation of the trachea. The upper end of the lower segment of the cesophagus opens into the trachea at the bifurcation or a short distance above, forming an osophagotracheal fistula. In some cases the cesophagus opens into a bronchus. The embryological significance of this abnormality is not fully understood, but it evidently is an expression of an early fundamental change in the embryo. It is not surprising that such abnormalities should sometimes occur when we consider the intricacies of the development of this region. 


\section{Symptomatology.}

The clinical picture is constant. The child may show other malformations such as imperforate anus, or it may be well and normally developed. An unusual amount of mucus is constantly expelled from the mouth. When fed, the child swallows once or twice without trouble, but after this it commences to regurgitate through the mouth and nose which become full of food and mucus. The child becomes cyanosed and coughs violently. This series of events occurs every time the child attempts to take food, but death rarely occurs from asphyxia. On abdominal examination the stomach is seen to be distended and the rest of the abdomen is flattened. The child soon becomes dehydrated, the tissues are dry, the anterior fontanelle is depressed and the stools are scanty. Broncho-pneumonia generally supervenes and is the immediate cause of death.

\section{Diagnosis.}

The above symptomatology is pathognomonic of complete œsophageal stenosis with an cesophago-tracheal fistula. The diagnosis can be confirmed by a radiogram after the child is given bariumised milk to swallow. A clear definition is obtained of the pouch formed by the upper segment of the oesophagus. An abnormal amount of gas may be noted in the stomach.

\section{Treatment.}

Immediately the diagnosis is made, all feeding by the mouth must cease. The best method of administering nourishment has to be determined. The rectal and subcutaneous routes cannot be used indefinitely. Esophagostomy, using the lower segment of the osophagus, is unsuitable because of the fistulous opening into the trachea. Gastrostomy has the same disadvantage, fluid may pass from the stomach into the lungs by way of the osophago-tracheal fistula. If gastrostomy is performed the lower segment of the oesophagus should be occluded and unless this is done gastrostomy is contraindicated. Jejunostomy obviates the disadvantage of regurgitation of food into the lungs. If the child survives this procedure it may be possible to attempt restoration of the continuity of the esophagus with closure of the fistula.

At the present time the prognosis is very unfavourable.

\section{2.-Simple Csophageal Stenosis.}

The degree of stenosis may vary within wide limits. There may be complete obliteration of the lumen of the oesophagus. In such cases the middle third of the oesophagus consists of a solid cord connecting the two pouches formed by the upper and lower thirds of the osophagus. This anomaly reminds us that in early embryonic life the oesophagus is composed of a solid cord of cells and secondarily acquires a lumen by a process of vacuolation. The symptomatology is similar to that of the preceding variety although pulmonary complications occur less frequently and death results from inanition. The treatment is gastrostomy. 
In other cases the œsophagus is partially obliterated. This may involve a small segment forming a ring stricture or a greater length may be affected. Such strictures are generally found in the lower third of the œsophagus, but the upper end is not immune. The symptoms are dysphagia, regurgitation of food and wasting. In order that the exact type of stricture may be determined a careful radiological examination should be instituted and it is advisable to perform œsophagoscopy. The treatment of these patients consists of slow dilatation of the stricture with graduated bougies. Rapid dilatation is dangerous as the œsophagus may be ruptured. At the first treatment a bougie is passed which will just fit the stricture under direct vision. Subsequent treatments may be carried out twice a week using increasing sizes of bougie. For a time it is advisable to pass the bougies under direct vision; later they may be passed blindly.

\section{3.-Membranous Usophageal Strictures.}

This variety of congenital stenosis is most amenable to treatment, hence it is important to recognise it. There are two varieties-a ring-like fold of mucous membrane or a complete membranous diaphragm stretching across the lumen of the œsophagus.

\section{Symptomatology.}

If the stenosis consists of a ring-like fold of mucous membrane, symptoms may not be apparent until the child commences to take solid food. The chief symptoms are dysphagia and regurgitation of unaltered food. The child is wasted and under-developed.

If the obstruction consists of a complete membranous diaphragm, dysphagia is present from birth and all food is regurgitated.

The investigation of this type of case consists of a radiological examination and, more important still, an examination with the osophagoscope whereby the type and degree of stenosis is seen. Regarding patients with the complete membraneous diaphragm, it is of the greatest importance to make sure of the continuity of the œesophagus below the membrane, hence Findlay has stressed the advisability of administering bariumised milk through the mouth and also through a gastrostomy whereby the continuity of the upper and lower segments of the œsophagus can be established.

\section{Treatment.}

(a).-Ring-like Membranous Stricture.

In the first instance an attempt should be made to dilate the stricture with graduated bougies under direct vision. If this is unsuccessful, internal osophagotomy may be performed as recommended by A. L. Abel.

\section{(b).-Membranous Diaphragm.}

The treatment consists in perforation of the membranous diaphragm providing there is continuity between the upper and lower segments of the osophagus. This may be done with a bougie passed under direct vision or with the oesophagoscope itself. A. L. Abel successfully treated a patient by the latter method. 


\section{Importance of recognising the type of congenital abnormality of the Esophagus.}

It has been shown that certain anomalies of the œsophagus at present lead to the death of the patient. However, it is not unreasonable to hope that with the continued development of œsophageal surgery something may eventually be done for these patients. It is clear that a great deal can be done to help patients with certain types of abnormality of the osophagus and it is only by recognising the exact type that appropriate treatment can be applied. Therefore a fatalistic attitude should not be adopted when we are confronted with a case of partial or complete dysphagia in infancy but every effort should be made to obtain a correct diagnosis.

\section{B.-Spasmodic Stricture of the Esophagus. \\ 1.-Cardiospasm.}

The etiology of this disease is still obscure. Important contributions have been made by A. F. Hurst and G. W. Rake on the relationship of degeneration of the ganglion cells of Auerbach's plexus and cardiospasm and Brown Kelly admirably reviewed the subject in the Semon Lecture in I926. Attention i\$ called to a few points in connection with the symptomatology and treatment.

\section{Symptomatology.-First Stage.}

The onset of the disease is most insidious and the underlying cause of the vague symptoms expressed may be unsuspected so that the patient may continue for months without a diagnosis being made. The discomfort complained of is temporary and there may be long remissions. There may be occasional mild dysphagia and a feeling of weight in the epigastrium which is relieved by drinking fluids or by regurgitation. Hiccough is sometimes present.

\section{Second Stage.}

The dysphagia is now pronounced and at times there may be complete obstruction. Difficulty may be experienced in swallowing liquids as well as solids; patients with benign and malignant neoplasms have difficulty in swallowing solids in the first instance and liquids later. Regurgitation of food is a prominent symptom and excessive salivation is present. A. F. Hurst has pointed out that the weight of the column of food in the dilated osophagus after a meal is sufficient to force a small proportion of the food through the cardiac orifice inte the stomach; as soon as the weight of the column falls below a certain point the flow ceases. The general health remains good but weight is lost.

\section{Third Stage.}

Prolonged dysphagia and regurgitation of food reduce the patient to emaciation and invalid life begins. If appropriate treatment is not given death occurs from starvation. 


\section{Radiological Appearances.}

It is important to make a radiological examination in the early stage during an attack. At first the cardiac end of the osophagus is tightly closed and nothing will pass through it in spite of active peristalsis in the osophagus. When there is a column of barium above the stricture, dilatation occurs and barium enters the stomach and is seen as a fine straight line. In a later stage marked dilatation of the œsophagus above the stricture occurs. In malignant stricture, there is very little dilatation of the œsophagus and the lumen through the stricture is markedly irregular. Compare Figs. I and 2.

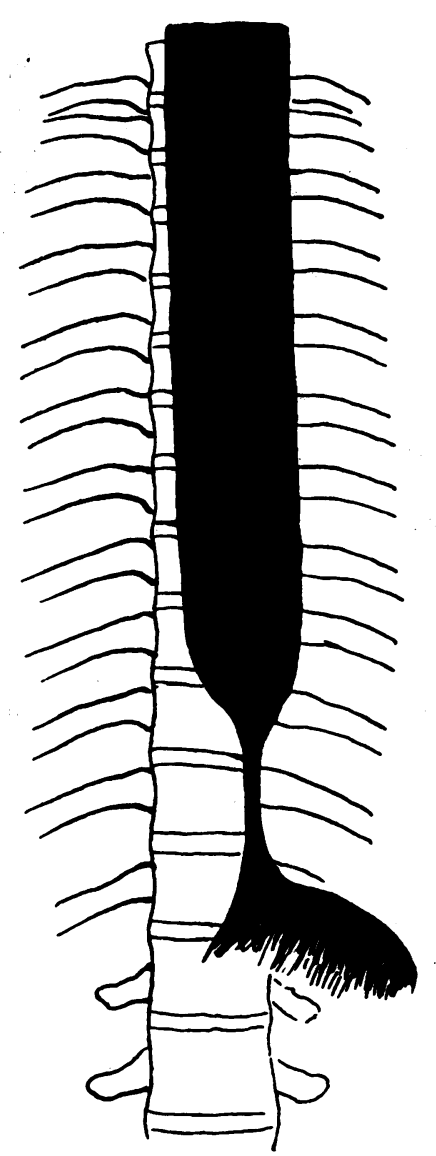

Fig. 1. - Drawing of X-ray appearances seen in Cardiospasm showing dilatation of œsophagus, and the sharp outline of the tapering lower end. The outline of the stricture is smooth.

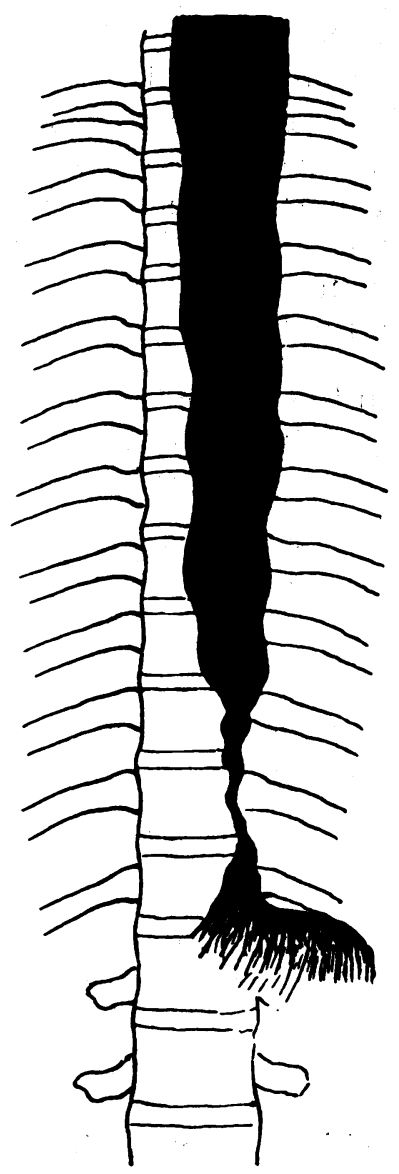

Fig. 2. - Drawing of X-ray appearances seen in Carcinoma of the cardiac end of the œsophagus. There is moderate dilatation of the œsophagus with marked irregularity of the cardiac end occupied by a carcinoma. Spasmodic contractions are seen in the œsophagus. 


\section{Treatment.}

The general health of the patient must be improved as much as possible and $c$ all sources of worry eliminated. All food must be thoroughly masticated and an $\stackrel{\vec{F}}{\rightarrow}$ effort made to swallow. The patient will decide which is the best position in which to ingest food. value.

Antispasmodic drugs have been employed but it is doubtful if they are of any

The simplest method of overcoming the stricture is by means of dilatation. A. F. Hurst has used a mercury tube with success. The tube has a round end and is filled with mercury. Two marks are made on the tube $I 6$ and $I 7$ inches from the lower rounded end. The tube should be 20 gauge at first and later 24 gauge. The patient can learn to pass the tube before a meal. It drops through the cardia into the stomach and is kept between the teeth at the I6-I7 inch marks for a few minutes and is then withdrawn. Hurst recommends that during the first week of treatment four daily feeds are given to the patient, each consisting of one pint of milk containing a beaten-up egg. Normal diet should be resumed gradually and should not contain rough particles of food.

When the above treatment fails forcible dilatation may be attempted by means of a hydrostatic bag. P. P. Vinson states that few patients are completely cured and recurrences occur in twenty five per cent. within six months.

Dilatation has been carried out successfully from below by a digital methos through the stomach.

Cardiosplasty has also been employed.

For the most intractable cases whose lives are a burden to themselves the operation of œsophago-gastrostomy may prove entirely successful.

\section{2.-Dysphagia with Anæmia.}

This is not an uncommon condition and the etiology is at present obscure Most of the recorded cases have been middle-aged women.

\section{Symptomatology.}

The chief symptom is dysphagia. Food is prevented from entering the œsophagus owing to spasm of the sphincter guarding the orifice. In the early stages of the disease the mucous membrane of the mouth and pharynx appears pale and the tongue is devoid of papillæ. Later the mucous membrane becomes dry and atrophic. There may be enlargement of the spleen. The blood picture is that of a mild secondary anæmia. An important contribution to the problem has recently been made by Graham and Johnson. These observers investigated the fragility of the red blood corpuscles and found it to be increased. They postulate a new specific type of anæmia with secondary changes in the mucous membrane of the tongue, mouth and osophagus with subsequent dysphagia. 


\section{C.-Organic Stricture of the Esophagus.}

\section{I.-Non-Malignant Stricture.}

I propose to say very little concerning this type of stricture which generally follows damage to the oesophagus by swallowing corrosives. The most favourable site for the effective treatment of such strictures is at the lower end. Grey Turner has recently had striking success in such cases with the operation of œsophago-gastrostomy.

\section{2.-Carcinomatous Stricture.}

Cancer of the œsophagus is more common than is generally supposed, and the mortality from the disease up to the present time is nearly Ioo per cent. Recently much experimental work has been done and surgeons have successfully operated on patients with gratifying immediate results. It is possible to excise the whole œesophagus and a new tube can be constructed which will serve the act of deglutition. We are merely touching the fringe of success in this difficult problem and it is important to enquire how further advance can be effected. Probably the most important factor is earlier diagnosis. The primary responsibility rests with the practitioner to whom the patient first applies for help. In many cases far too much valuable time has been lost because the importance of certain vague symptoms has been overlooked.

It is a mistake to consider palliative treatment only for cancer of the œsophagus. This has been largely done in the past, but in the light of recent work it is unjustifiable. The suggestion has been made that cancer of the cesophagus gives rise to metastases early in the course of the disease. Abel quotes Blauwkuip, who examined I25 cases post mortem and found that 64 per cent. showed no metastases in distant organs; in 47 per cent. no glandular involvement had occurred and in 39 per cent. the disease was localised in the osophagus. I have studied the autopsy findings in 5I cases of cancer of the œsophagus and in my series 2I per cent. were free from any metastases. I maintain that these figures of themselves are most encouraging and most probably underestimate the incidence with which the mischief would be found to be local at operation.

\section{Symptomatology. 1.-Early Symptoms.}

These appear to be vague and are often considered to be trifling, but nevertheless are of the greatest importance as they call attention to the onset of an insidious disease. Chevalier Jackson has elicited the following early symptoms from patients with cancer of the cesophagus and they are given as nearly as possible in the patients' own words: 
I. "Slight, queer feeling in swallowing ; but food went down all right."

2. "A feeling of nervousness about starting to swallow; after starting, food went down without any trouble."

3. "A feeling of nervousness in the neck."

4. "Vague sensation about the neck as of something wrong."

5. "A feeling of cramp around the neck."

6. "A feeling as if my swallow was not working right, but nothing seemed to stick until lately."

7. "Food sticking in the throat while eating in a hurry; but it went down itself all right, and I had no trouble for months afterwards, though I did not eat in a hurry any more."

8. "A feeling as of a lump rising in my throat."

Cough is sometimes an early symptom.

\section{Late Symptoms.}

It must be remembered that the following symptoms indicate an advanced stage of the disease: dysphagia for solid food, and latterly even for liquids, regurgitation of unaltered food, excessive salivation, night cough and pain in the chest. Hoarseness is nearly always present and progressive loss of weight.

\section{Diagnosis.}

Radiography.-This should be carefully carried out in all patients in whom an osophageal carcinoma is suspected. This will not only reveal signs of malignancy but will exclude extra-œsophageal pressure such as aneuysm of the aorta. If possible stereoscopic pictures should be made so that information is available concerning the lateral extent of the neoplasm. The radiological appearances are shown in Fig. 2.

Esophagoscopy.-By this means cancer of the osophagus can be diagnosed with certainty and a small piece can be removed for microscopic examination. The type of growth is noted together with its size and the degree of stenosis of the osophagus.

\section{Treatment.}

The treatment of cancer of the œsophagus resolves itself into either an attempt to eradicate the disease or merely palliation of the disease. 


\section{(a).-Radical.}

This should be attempted in all suitable cases as it gives the patient his only chance of life. The suitable case is the patient in whom it is considered after careful investigation that the carcinoma has not extended beyond the osophagus and whose general condition warrants a major surgical operation. Careful attention should be given to eradicate all foci of infection from the mouth. A preliminary jejunostomy is preferable to gastrostomy and as much nourishment is given by this channel as possible. It may be a month before the patient is ready for operation on the esophagus and the surgeon must judge when the maximum benefit has been derived from the jejunostomy. At the present time the operation of choice is complete esophagectomy with closure of the lower end of the œsophagus; the upper end is brought out on to the neck forming a temporary fistula. Later a new œsophagus is constructed by means of skin flaps on the front of the chest. There are distinct possibilities from this method. L.O'Shaughnessy has undertaken experimental work with the object of mobilising the stomach into the thorax and anastomosing the divided œsophagus to the stomach and thus restoring continuity. There are distinct possibilities in this method.

\section{(b).-Palliative.}

\section{I.-Gastrostomy.}

Grey Turner strongly advocates this procedure as a palliative measure and has carried it out in nearly two hundred cases without any unpleasant complications. The operation should be performed early before the patient is in the last stage of starvation. In these circumstances many months may be added to the patient's life.

\section{2.-Intubation.}

For carcinomatous strictures through which a bougie can be passed various intubation tubes have been devised. The most satisfactory one is probably Souttar's tube, which is made of coiled nickel or German silver wire. The stricture is dilated to the required size and the tube is introduced into the stricture under direct vision. The patient can then swallow semi-solid and liquid foods with comparative ease. Care must be taken that the tube does not become blocked with food. In some cases the tube passes through the stricture into the stomach but this need occasion no alarm for it emerges per rectum.

\section{3.-Dilatation.}

Some surgeons advocate dilation of carcinomatous strictures which have not completely occluded the lumen. Graduated bougies are passed through the growth under direct vision at frequent intervals. There are several objections to 
this method. It appears unwise to traumatise a malignant growth and there may be severe hæmorrhage. The œsophagus may be perforated with resulting acute mediastinitis.

\section{4.-Radium.}

Up to the present the results from radium in the treatment of cancer of the œsophagus are disappointing. It may be that we have not yet devised the right method of irradiating the growth which does appear to be radio-sensitive.

\section{5.-Deep X-Ray Therapy.}

Different opinions are held regarding the value of deep X-ray therapy for cancer of the osophagus. Abel states that at Jackson's clinic, gastrostomy together with deep $\mathrm{X}$-ray therapy has proved to be the best palliative treatment.

\section{REFERENCES.}

Congenital Malformations.

Abel, A. L.-Brit. Med Journ., 1928, ii. 46.

Brenneman, J.-Amer. Journ. Dis. Child., 1918, xvi. 143.

Cautley, E.-Brit. Journ. Dis. Child., 1917, xiv. 1.

Findlay, L. \& Kelly, A. B., Proc. Roy. Soc. Med., 1931, xxiv (Sect. Laryng. 85).

Findlay, L.-Acta Pædiatrica, 1932, xiii. 70.

Griffiths, J. P. C. and Lavenson, R. S.-Arch. Pediat., 1909, xxvi. 161.

Hess, J. H.-Med. Clin. N. Amer. (Chicago No.), 1923, vii. 499.

Hirsch, I. S.-Journ. Amer. Med. Assoc., 1921, 1xxvi. 1491.

Hutchison, R.-Proc. Roy. Soc. Med., 1923, xvi. 42.

Mayo, C. H.-Ann. Surg., 1923, lxxvii. 267.

Reynolds, R. P. and Morrison, W. W.-Amer. Journ. Dis. Child., 1921, xxi. 339.

Vinson, P. P.-Collected Papers of the Mayo Clinic, 1923, xv. 3.

\section{Cardiospasm.}

Hurst, A. F.-Quart. Journ. Med. 1914-15, viii. 300.

-Lancet, 1927, i. 618 and 667.

Kelly, A. Brown.-Journ. Laryngol, 1927, xlii. 221.

Rake, G. W.-Guy's Hosp. Reps. 1927. Series iv. vol. 7, 141.

Dysphagia AND ANemia.

Cameron, J. A. Munro.-Quart. Journ. Med., 1928-29, xxii. 43.

Graham, G. and Johnson, R. S.-Quart. Journ. Med., 1932, xxv. 41.

\section{Carcinoma.}

Abel, A. L.-Esophageal Obstruction, 1929.

Jackson, Chevalier.-Amer. Journ. Med. Sci., 1925, clxix. 625.

O'Shaughnessy, L.-The Med. Press and Circ. 1933, cxxxv. 150.

Raven, R. W.-St. Bart. Hosp. Reps., 1931, lxiv, 181.

Souttar, H. S.-Briț. Journ Surg., 1927-28, xv. 76.

Turner Grey, G.-New Eng. Jour. of Med., 1931, œv. 657. 